(C) 2016

Гарбар Л. А., кандидат сільськогосподарських наук, Антал Т. В., кандидат сільськогосподарських наук, Романов С. М., бакалавр

Національний університет біоресурсів і природокористування України

\title{
ОСОБЛИВОСТІ ФОРМУВАННЯ ПРОДУКТИВНОСТІ ПОСІВІВ РІПАКУ ЯРОГО ЗА ВПЛИВУ НОРМ ВИСІВУ ТА УДОБРЕННЯ
}

\section{Рецензент - кандидат сільськогосподарських наук Н. П. Бордюжа}

Наведено результати досліджень, спрямованих на вивчення впливу застосування мінеральних добрив та норм висіву насіння на формування продуктивності посівів різних сортів ріпаку ярого. Дослідження проводились протягом 2013-2015 рр. в умовах Черкаської області на чорноземах типових. У результаті проведених нами досліджень встановлено, щзо на чорноземах типових малогумусних в умовах Лісостепу України найвищий приріст врожаю насіння ріпаку ярого сортів Магнат та Сіріус формусться за внесення мінеральних добрив у нормі $N_{70} P_{40} K_{70}$ та нормі висіву насіння 1,2 млн схожих насінин на 1 гектарі.

Ключові слова: ріпак ярий, удобрення, норма висіву, сорти, урожайність, якість.

Постановка проблеми. Суттєвий вплив на формування продуктивності ріпаку ярого, як i всіх рослин родини капустяних, має поряд зі способами та строками сівби норма висіву. Суперечливі дані щодо норм висіву озимого та ярого ріпаку спричиняють перевитрати насіння або недобір урожаю, а в кінцевому результаті - зниження ефективності ріпаківництва як галузі взагалі. Водночас ярому ріпаку приділяють значну увагу, як одній із найпоширеніших олійних культур $[1,2]$.

Аналіз останніх досліджень і публікацій, у яких започатковано розв'язання проблеми. Завдяки біологічній особливості ріпаку - формувати на зріджених посівах багато бічних пагонів, а на загущених - підвищену кількість стручків у верхній частині рослини - норми висіву його значно менше, ніж в інших культур впливають на врожайність.

Канадськими вченими було встановлено, що збільшення норми висіву насіння майже вп'ятеро (з 2 до 11,2 кг/га) не мало істотного впливу на врожайність посівів. Вона варіювала в межах від 12,4 до 13,7 ц/га. Шведські дослідники, висіявши від 5 до 20 кг/га насіння, отримали майже однакову кількість олії. Оптимальною в цій країні вважається густота 200-300 рослин на $1 \mathrm{~m}^{2}$. За $90 \%$ схожості та за ширини міжрядь $12-$ 24 см норма висіву становить 9-12 кг/га. Проте за несприятливих умов іiї можна дещо збільшити. У Данії, Франції, Англії на сівбу витрачають 5-7 кг/га насіння, що відповідає $120-150$ рослинам на $1 \mathrm{~m}^{2}$ [3].

Загущені посіви сприяють витягуванню центрального пагона рослини. Підвищена густота стояння рослин ріпаку ярого в процесі вегетації нерідко призводять до вилягання рослин, що в свою чергу призводить до запізнення цвітіння та нерівномірного дозрівання. Загущені посіви спричиняють як погіршення якості насіння, так i значні його втрати. У рослин ріпаку ярого закладка бічних пагонів відбувається незалежно від густоти стеблостою. Водночас висока конкуренція у загущених посівах негативно впливає на розвиток рослин та на кількість стручків на рослині. Це, зокрема, призводить до зниження урожайності у гібридів, які відрізняються великою здатністю до гілкування. Підвищені норми висіву викликають збільшення густоти стояння рослин, що призводить до їх вилягання, пізнього цвітіння і не достигання насіння $[3,4]$.

За визначення оптимальної норми висіву ріпаку ярого варто враховувати такі важливі фактори, як тип грунту, сортові особливості досліджуваної культури, строки сівби, якість підготовки насіннєвого ложе, погодних умов тощо. За ранніх строків сівби варто використовувати більш низькі норми, а в разі запізнення 3 сівбою більш високі норми висіву.

Встановлено, що норми висіву насіння 4 і 6 кг/га практично забезпечують однаковий рівень урожайності як за ширини міжрядь 15 , так і 30 см, у той час як за міжряддя 45 см урожайність знижується. Результати показують, що оптимальна густота стояння рослин ріпаку ярого забезпечує нормальний біологічний розвиток культури. Для створення такої густоти рослин норма висіву повинна бути в межах $0,8-1,2$ млн схожих насінин/га. Необгрунтоване підвищення норми висіву спричиняє біологічну конкуренцію рослин у процесі їх росту та розвитку, внаслідок чого рослини витягуються, а точка росту і коренева ший- 
ка виносяться на поверхню грунту [4].

Водночас було виявлено і вплив норм висіву на вміст і вихід олії з насіння ріпаку ярого. Вміст жиру в насінні ріпаку ярого знижувався за збільшення норм висіву до 2,0 і 2,5 млн схожих насінин на га, а ширини міжрядь - до 30 і 45 см [4].

Аналіз наукових робіт свідчить, що в умовах Лісостепу України такі елементи агротехніки ріпаку ярого, як норми висіву, заслуговують більшої уваги, поскільки дані питання висвітлені у науковій літературі неоднозначно і є актуальними для подальшого вивчення.

Метою досліджень було встановлення впливу застосування мінеральних добрив та норм висіву насіння на формування продуктивності посівів ріпаку ярого в умовах Черкаської області.

Матеріали і методи досліджень. Схемою досліду передбачено вивчення наступних факторів: фактор А - норми висіву: 0,8; 1,0; 1,2; 1,4, 1,6 млн схожих насінин/га, фактор Б - норми внесення добрив: 1. Без добрив (контроль); 2. $\mathrm{N}_{35} \mathrm{P}_{20} \mathrm{~K}_{35}$; 3. $\mathrm{N}_{70} \mathrm{P}_{40} \mathrm{~K}_{70}$; $\mathrm{C}-$ сорти Магнат, Cipiyc.

Основним показником реалізації біологічного потенціалу культури, залежно від досліджуваних факторів, є врожайність. Динаміка змін рівнів врожайності під впливом вивчених факторів наведена в таблиці 1.

Результати досліджень свідчать, що досліджувані сорти по-різному реагували як на зміну норм висіву, так і на застосування добрив. Варто зазначити те, що збільшення норм висіву до 1,2 млн схожих насінин на га сприяло отриманню суттєвих приростів врожаю. Подальше підвищення норм висіву на варіанті без добрив та за внесен- ня $\mathrm{N}_{35} \mathrm{P}_{20} \mathrm{~K}_{35}$ призвело до несуттєвого підвищення урожайності культури. Дещо інша тенденція спостерігалась на варіанті із застосуванням $\mathrm{N}_{70} \mathrm{P}_{40} \mathrm{~K}_{70}$. За даної норми добрив підвищення врожайності спостерігалось на варіантах 3 нормами висіву до 1,2 млн схожих насінин на гектар. Подальше підвищення норм висіву призвело до незначного зниження останньої. Така залежність простежувалась у обох досліджуваних сортів.

Під час досліджень було встановлено, що використання високих норм висіву призводить до утворення меншої кількості гілок на рослинах та формування на них меншої кількості стручків, а в комплексі 3 підвищеними нормами добрив та достатньою кількістю вологи спостерігається витягування рослин, в результаті конкуренції та їх вилягання.

Варто відмітити, що досліджувані сорти ріпаку ярого виявили різну чутливість і до внесення мінеральних добрив. Зі збільшенням норм удобрення спостерігалось підвищення урожайності насіння даної культури.

Залежно від сорту та норми висіву урожайність насіння ріпаку варіювала зі збільшенням норм добрив за вирощування сорту Магнат від 1,32 т/га (варіант без добрив, норма висіву 0,8 млн/га схожих насінин) до 2,91 т/га (варіант із застосуванням $\mathrm{N}_{70} \mathrm{P}_{40} \mathrm{~K}_{70}$ та нормою висіву 1,2 млн/га схожих насінин та сорту Сіріус відповідно від 1,46 до 3,02 т/га.

Основною метою вирощування ріпаку ярого $\epsilon$ отримання олії, вміст якої в насінні становить до $44 \%$ маси.

1. Урожсайність насіння ріпаку ярого у польовому досліді, m/za (середнє 2013-2015 рр.)

\begin{tabular}{|c|c|c|c|c|}
\hline \multirow{2}{*}{ Сорт } & \multirow{2}{*}{$\begin{array}{c}\text { Норма висіву, } \\
\text { млн схожих } \\
\text { насінин/га }\end{array}$} & \multicolumn{3}{|c|}{ Норми удобрення } \\
\hline & & $\begin{array}{l}\text { без добрив } \\
\text { (контроль) }\end{array}$ & $\mathrm{N}_{35} \mathrm{P}_{20} \mathrm{~K}_{35}$ & $\mathrm{~N}_{70} \mathrm{P}_{40} \mathrm{~K}_{70}$ \\
\hline \multirow{5}{*}{ Магнат } & 0,8 & 1,32 & 1,62 & 1,88 \\
\hline & 1,0 & 1,65 & 1,87 & 2,36 \\
\hline & 1,2 & 2,16 & 2,28 & 2,91 \\
\hline & 1,4 & 2,18 & 2,31 & 2,78 \\
\hline & 1,6 & 2,21 & 2,34 & 2,70 \\
\hline \multirow{5}{*}{ Cipiyc } & 0,8 & 1,46 & 1,86 & 2,07 \\
\hline & 1,0 & 1,69 & 1,98 & 2,47 \\
\hline & 1,2 & 1,78 & 2,33 & 3,02 \\
\hline & 1,4 & 1,91 & 2,41 & 2,90 \\
\hline & 1,6 & 1,97 & 2,43 & 2,81 \\
\hline
\end{tabular}


СІЛЬСЬКЕ ГОСПОДАРСТВО. РОСЛИННИЦТВО

\section{2. Показники якості насіння ріпаку ярого, середн (2013-2015 рр.)}

\begin{tabular}{|c|c|c|c|c|c|c|c|}
\hline \multirow{3}{*}{ Сорт } & \multirow{3}{*}{$\begin{array}{c}\text { Норма висіву, } \\
\text { млн схожих } \\
\text { насінин/га }\end{array}$} & \multicolumn{6}{|c|}{ Показники якості } \\
\hline & & $\begin{array}{c}\text { вміст } \\
\text { жиру, \% }\end{array}$ & $\begin{array}{c}\text { вміст } \\
\text { білку, \% }\end{array}$ & $\begin{array}{c}\text { вміст } \\
\text { жиру, \% }\end{array}$ & $\begin{array}{c}\text { вміст } \\
\text { білку, \% }\end{array}$ & $\begin{array}{c}\text { вміст } \\
\text { жиру, \% }\end{array}$ & вміст білку, \% \\
\hline & & \multicolumn{2}{|c|}{ без добрив } & \multicolumn{2}{|c|}{$\mathrm{N}_{35} \mathrm{P}_{20} \mathrm{~K}_{35}$} & \multicolumn{2}{|c|}{$\mathrm{N}_{70} \mathrm{P}_{40} \mathrm{~K}_{70}$} \\
\hline \multirow{5}{*}{ Магнат } & 0,8 & 41,93 & 20,84 & 41,62 & 21,04 & 41,41 & 21,29 \\
\hline & 1,0 & 41,78 & 20,81 & 41,35 & 20,93 & 41,14 & 21,18 \\
\hline & 1,2 & 41,76 & 20,76 & 41,16 & 20,88 & 40,95 & 21,09 \\
\hline & 1,4 & 41,56 & 20,74 & 41,11 & 20,84 & 40,90 & 21,01 \\
\hline & 1,6 & 41,45 & 20,66 & 41,06 & 20,76 & 40,87 & 20,89 \\
\hline \multirow{5}{*}{ Cipiyc } & 0,8 & 42,23 & 21,64 & 41,99 & 21,64 & 41,78 & 21,96 \\
\hline & 1,0 & 42,11 & 21,51 & 41,89 & 21,59 & 41,68 & 21,81 \\
\hline & 1,2 & 42,03 & 21,41 & 41,84 & 21,52 & 41,63 & 21,69 \\
\hline & 1,4 & 41,96 & 21,24 & 41,62 & 21,46 & 41,41 & 21,54 \\
\hline & 1,6 & 41,80 & 21,11 & 41,35 & 20,28 & 41,14 & 21,46 \\
\hline
\end{tabular}

Особливістю олії ріпаку є те, що вона за складом жирних кислот $є$ генетично більш різноманітна в порівнянні з іншими рослинними оліями. Насіння отримане з сучасних сортів ярого ріпаку, крім олії, містить 18-22 \% білку, 6-7 \% клітковини і 24-26\% безекстрактивних речовин.

Вміст жиру в насінні ріпаку може змінюватись під впливом як грунтово-кліматичних умов певного регіону, так і під впливом елементів технології вирощування. Дослідження свідчать, що підвищення доз азоту призводить до зниження вмісту жиру в насінні, при цьому вміст сирого протеїну може збільшуватись на $1-2 \%$.

Проаналізувавши показники якісного складу насіння варто відмітити, що вміст жиру в насінні ріпаку ярого зі збільшенням норм застосування добрив зменшувався (табл. 2).

\section{БІБЛІОГРАФІЯ}

1. Вишнівський П. С. Перспективна культура України - ріпак / П. С. Вишнівський // Зб. наук. праць Інституту землеробства УААН. - К., 2000. Вип. 3-4. - С. 81-83.

2. Вишневський П. І. Виробництво озимого та ярого ріпаку в Лісостепу України / П. І. Вишневський, І. Д. Ситнік, І. Л. Антонік. - К. : Національний аграрний ун-т УААН, товариство «Знання»
Таким чином, найвищий вміст жиру було отримано на варіантах без застосування добрив. Дана закономірність простежувалась в обох досліджуваних сортів. При цьому в разі підвищення норм висіву спостерігалась тенденція до зниження вмісту жиру в насінні ріпаку. Водночас застосування добрив сприяло накопиченню білку в насінні.

Висновок. У результаті проведених нами досліджень встановлено, що на чорноземах типових малогумусних в умовах Лісостепу України найвищий приріст врожаю насіння ріпаку ярого сортів Магнат та Сіріус формується в разі внесення мінеральних добрив у нормі $\mathrm{N}_{70} \mathrm{P}_{40} \mathrm{~K}_{70}$ та норми висіву насіння 1,2 млн схожих насінин на 1 гектар.

України, 2001.

3. Синягин И. И. Площади питания растений / И. И. Синягин. - М. : Россельхозиздат, 1975. $382 \mathrm{c}$.

4. Рапс и сурепица / [Шпаар Д. и др.] ; под общей редакцией Д. Шпаара // Выращивание, уборка, использование. - М. : ИД OOO «DLV АГРОДЕЛО», 2007. - 320 с. 